Members of Council and officers of the Society are as follow : President, Sir George Thomson; Members of Council, Dr. W. J. Clark, Mr. R. E. Iggledon, Mr. G. H. Farrington, Mr. F. C. Knowles, Dr. W. F. Higgins, Mr. D. A. Oliver, Mr. W. B. Wright, Dr. H. S. Gregory, Mr. C. R. Sams, Dr. E. Griffiths, Mr. E. B. Moss and Prof. F. Debenham; Hon. Treasurer, Dr. H. B. Cronshaw ; Hon. Secretary, Mr. L. B. Lambert, 55 Tudor Gardens, London, W.3. It is intended to call a general meeting, probably in the early autumn, at which the constitution and rules, as recommended by the Council, will be sub. mitted for the formal approval of intending members.

\section{Supply and Allocation of Raw Materials}

THE second annual report of the Combined Raw Materials Board, to January 26, 1944 (London : H.M. Stationery Office, 2d. net), states that the policy of the Board during 1943 has been to concentrate on those materials which were vital to the war effort, were actually or potentially scarce during 1942 , and continued to demand action on a combined basis for their effective utilization. The principal metals, and the alloying metals, tungsten, cobalt, molybdenum, vanadium, chromium and manganese, have remained under continuous supervision, while supplies of rubber and hard fibres for rope-making remained critical and demanded continual attention and drastic action. Electrical and instrument programmes in connexion with aircraft and military equipment gave rise to great anxiety regarding mica and especially certain critical grades of it ; the $\operatorname{sam} \theta$ problem of securing an adequate supply and the proper distribution of critical grades brought asbestos within the scope of the Board. The liberation of Madagascar late in 1942 led to a co-ordinated review of supplies of graphite and their allocation, and the loss of practically all supplies of silk at the time when the joint parachute programmes were making heavy calls brought the alternative synthetic fibre 'Nylon' under the Board's supervision. The output of adequate supplies of balsa wood had to be assured to make possible the production of Mosquito aircraft, while balata, bismuth, bristles, mexcury, rotenone, pyrethrum and hides all came or were maintained under review during the year.

The nature of the Board's allocations has varied according to the complexity and acuteness of its problems. To ensure the maximum desired or practicable production of a material, and also that each country uses scarce materials economically, the Board works in the closest contact with the operating departments. Problems of shipping and transport have been of prime importance, and certain problems have been treated on an area basis. Combined committees for copper and steel which had been set up in association with the Combined Production and Resources Board at the end of 1942 were supplemented during 1943 by similar committees for aluminium and magnesium, coal, footwear, leather and hides, and pulp and paper. The overall raw materials position did not change radically during 1943 ; but serious new shortages developed in hides and wood pulp, and a Joint Hide Control Office was set up in Washington to co-ordinate the procurement of overseas hides. The overall stringency is likely to continue indefinitely and well into the post-war period, while a combined committee which investigated the forest products situation reported in October that to maintain minimum supplies of pulp products direct action would be necessary to replenish the labour force in the forests and maintain it at the necessary level. Some measure of curtailment of paper consumption is also considered inevitable.

Towards the end of 1943 , the Board was faced with new problems of materials coming or likely to come into partly surplus supply, and, in common with the other combined boards, the functions of the Board were also widened to include the responsibility for making allocations necessary to meet the raw material requirements of territories to be liberated from the enemy. There were no major developments during the year in the actual organization of the Board or its machinery. The final section of the report stresses the dependence of both the United States and the United Kingdom on raw materials from overseas, and the relatively ample endowment in raw materials on which they and the other allied industrial powers have been able to draw.

\section{Post-War Plans for Science}

A memorandum on "Post-war Plans for Science", issued by the Association of Scientific Workers, gives a precis of the statement "Scientific Research and the Universities", issued by the Parliamentary and Scientific Committee, and a more critical review of "A National Policy for Industry" issued by 120 industrialists and of the report "Industry and Research" issued by the Federation of British Industries Industrial Research Committee last autumn, all of which have been discussed in NaTURE. Commenting on the proposals by the industrialists for the closer organization of industry, the memorandum urges that organization of the community would be necessary to ensure that the spirit of the proposals is given effect and that the compulsory powers are not abused. With regard to the recommendations of the Federation of British Industries, the memorandum directs attention to the absence of any practical suggestion whereby the consumers or the State could participate in the decision whether certain work should be undertaken because the consumer requires it, or that the Department of Scientific Research should be encouraged to spend more on nationally owned and controlled research institutes for various industries where the results would be published for the benefit of all. While the memorandum sounds a warning against sectional interests being allowed to stunt proposals good and proper in themselves, and calls for a wider vision of the national interest, its criticism is marred by the subjective approach. The prejudice against private industry with which the memorandum starts appears to have clouded judgment to the extent that the writer is more concerned to voice suspicions of any proposals from such a source than to submit them to objective and impartial analysis.

\section{Mineral Resources of Tanganyika}

THE Department of Lands and Mines (Geological Division), Tanganyika Territory, has issued an account of the mineral resources of the Territory, prepared by Sir Edmund Teale and F. Oates (Bull. 16. Dar es Salaam, 1943. 15s.). This bulletin contains, in Part 1, an account of the relatively few mineral deposits that are, or have recently been worked in Tanganyika. Part 2 includes a much longer list of economic minerals the occurrence of which has been recorded in the Territory, though in many cases in small quantities only. Notes on the manner in which these minerals occur are given, with the view of assisting would-be prospectors. 
Further and more systematic exploration appears to be necessary before it can be said that the economic possibilities of these deposits can be properly assessed. Part 3 contains a summary of information regarding certain specially selected minerals, for consideration in reviewing the actual and potential mineral resources of Tanganyika, more particularly in regard to wartime requirements.

\section{Staff Selection}

A Paper (J. Inst. Elec. Eng., 91, Pt. 1, No. 40; April 1944) by Messrs. R. C. Woods and A. S. MacDonald discusses staff selection by scientific methods, and makes reference to the designing of tests and to the means of proving their usefulness. The use of statistical methods is considered, a number of tests being described and samples given. The application of these principles to the staff selection problems in a light electrical engineering factory is described, the procedure for staffing a new department is detailed, and reference is made to the other classes of labour which are dealt with in the factory. A note on the selection of engineer apprentices is included. The last section of the paper deals with the technique of the interview. Finally, the authors mention the origin and growth of their work as indicative of its usefulness, and refer to co-operation between various departments in the factory which are concerned with personnel.

\section{School Hygiene in Peru}

According to an annotation in the September issue of the Boletin de la Oficina Sanitaria Panamericana, school hygiene in Peru includes psychobiological investigation of childhood and adolescence, school health medical supervision and physical education. A special week is also set apart for an intensive programme in health education for the whole country. During the second half of $1941,10,000$ children between six and ten years were immunized against diphtheria. Medical examination of teachers before appointment has become the general practice. Sanatorium schools for tuberculous children, some of which are built in the higher altitudes with appropriate climatic conditions, have been established. Retarded children are being given attention and transferred to special schools.

\section{Earthquakes Registered in Spain}

DuRING January 1944, twenty-nine earthquakes were registered by the seismographs at the Geophysical Observatory at Toledo. The greatest of these happened on January 16 and registered at Toledo at $00 \mathrm{~h} .02 \mathrm{~m}$. 4Is., attaining a ground amplitude of $90 \mu$ at the Observatory. The earthquake was destructive in the province of San Juan in Argentina, South America. The nearest earthquake to Toledo during the month occurred on January 7 , when $e P_{g} z$ registered at $12 \mathrm{~h}$. $31 \mathrm{~m}$. $09 \mathrm{~s}$. from an estimated epicentral distance of $230 \mathrm{~km}$.

\section{Gas Industry in Great Britain}

THE Minister of Fuel and Power has appointed the following committee of inquiry into the gas industry : Mr. Geoffrey Heyworth (chairman), Mr. Stuart Cooper, Sir Jonathan Davidson, Mr. Gavin Martin and Prof. D. M. Newitt. The secretary of the committee will be Mr. A. F. James, of the Ministry of Fuel and Power, to whom all communications should be addressed at the Gas and Electricity Division,
Ministry of Fuel and Power, New Oxford House, Bloomsbury Way, W.C.l.

The terms of reference of the committee are: "To review the structure and organization of the gas industry, to advise what changes have now become necessary in order to develop and cheapen gas supplies to all types of consumers, and to make recommendations"?

\section{Announcements}

Frankin Medals for 1944 have been awarded to Dr. W. D. Coolidge, vice-president and director of research for the General Electric Company, for his development of the X-ray tube, and to Dr. P. Kapitza, director of the Institute for Physical Problems, Academy of Sciences of the U.S.S.R., for his work on extraordinarily high magnetic fields, and for designing an efficient liquid hydrogen machine.

Dr. S. Lrvingston Smrth, superintendent of the Engineering Department at the National Physical Laboratory, Teddington, has been appointed director of research of the British Shipbuilding Research Association recently formed by the Shipbuilding Conference in close co-operation with the Department of Scientific and Industrial Research.

DR. A. J. V. UNDERwood has resigned from the position of joint honorary secretary of the Institution of Chemical Engineers which he has held for the last eight years.

Dr. R. E. G. Armattoe, director of the Lomeshie Research Centre for Anthropology and Human Biology, and honorary physician in charge of Brooke Park (E.M.S.), Londonderry, has been elected a foreign member of the American Association of Physical Anthropologists.

Dr. Charles Ockrent, who has been working during the War in the Ministry of Supply and more recently has been acting in an advisory capacity in Scotland on the application of scientific control and instrumentation in industry, has been appointed to the scientific staff of the British Drug Houses, Ltd., as manager of production and development.

ThE following appointments have been made in the Colonial Service: R. D. Linton, agricultural officer, Tanganyika, to be senior agricultural officer, Tanganyika; G. W. Nye, deputy director of agriculture, Uganda, to be director of agriculture, Nyasaland; A. S. Richardson, director of agriculture, Nyasaland, to be director of agriculture, Uganda; E. G. Staples, senior agricultural officer, Uganda, to be director of agriculture, British Honduras; A. S. Stenhouse, agricultural officer, Tanganyika, to be senior agricultural officer, Tanganyika ; W. A. Burns, G. S. Cowin, M. A. Molloy and N. R. Reid, veterinary officers, Tanganyika, to be senior veterinary officers, Tanganyika.

WE have received from the Freshwater Biological Association a copy of Scientific Publication No. 8 which takes the form of "Keys to the British Species of Aquatic Megaloptera and Neuroptera", written by D. E. Kimmins of the British Museum (Natural History). It provides an admirable account of these insects accompanied by excellent original illustrations of their chief structural features. Its low price of 1s. 6d. should ensure it being in the hands not only of entomologists but also of all students of the freshwater fauna. It can be obtained from the Director, Freshwater Biological Association, Wray Castle, Ambleside, Westmorland. 